Article

\title{
Supplemental Effects of Biochar and Foliar Application of Ascorbic Acid on Physio-Biochemical Attributes of Barley (Hordeum vulgare L.) under Cadmium-Contaminated Soil
}

\author{
Samia Yaseen ${ }^{1}$, Syeda Fasiha Amjad ${ }^{1, *}$, Nida Mansoora ${ }^{1}$, Shameem Kausar ${ }^{1}$, Huma Shahid ${ }^{1}$, \\ Saad A. M. Alamri ${ }^{2}$, Sulaiman A. Alrumman ${ }^{2}$ (D) Ebrahem M. Eid 2,3 ${ }^{\mathbb{D}}$, Mohammad Javed Ansari ${ }^{4}$, \\ Subhan Danish ${ }^{5, * \mathbb{D}}$ and Rahul Datta ${ }^{6}$ (D)
}

Citation: Yaseen, S.; Amjad, S.F.; Mansoora, N.; Kausar, S.; Shahid, H.; Alamri, S.A.M.; Alrumman, S.A.; Eid, E.M.; Ansari, M.J.; Danish, S.; et al. Supplemental Effects of Biochar and Foliar Application of Ascorbic Acid on Physio-Biochemical Attributes of Barley (Hordeum vulgare L.) under Cadmium-Contaminated Soil. Sustainability 2021, 13, 9128. https://doi.org/10.3390/su13169128

Academic Editor: Teodor Rusu

Received: 26 June 2021

Accepted: 10 August 2021

Published: 14 August 2021

Publisher's Note: MDPI stays neutral with regard to jurisdictional claims in published maps and institutional affiliations.

Copyright: (c) 2021 by the authors. Licensee MDPI, Basel, Switzerland. This article is an open access article distributed under the terms and conditions of the Creative Commons Attribution (CC BY) license (https:// creativecommons.org/licenses/by/ $4.0 /)$.
1 Department of Botany, University of Agriculture Faisalabad, Punjab 38000, Pakistan; samiayasin69@gmail.com (S.Y.); nidamansoora6@gmail.com (N.M.); shameemkausar4@gmail.com (S.K.); humashahid98@gmail.com (H.S.)

2 Biology Department, College of Science, King Khalid University, Abha 61321, Saudi Arabia; saralomari@kku.edu.sa (S.A.M.A.); salrumman@kku.edu.sa (S.A.A.); ebrahem.eid@sci.kfs.edu.eg (E.M.E.)

3 Botany Department, Faculty of Science, Kafrelsheikh University, Kafr El-Sheikh 33516, Egypt

4 Department of Botany, Hindu College Moradabad, Mahatma Jyotiba Phule Rohilkhand University Bareilly, Moradabad 244001, India; mjavedansari@gmail.com

5 Department of Soil Science, Faculty of Agricultural Sciences and Technology, Bahauddin Zakariya University, Punjab 60800, Pakistan

6 Department of Geology and Pedology, Faculty of Forestry and Wood Technology, Mendel University in Brno, 61300 Brno, Czech Republic; rahulmedcure@gmail.com

* Correspondence: fasihamushadi75@gmail.com (S.F.A.); sd96850@gmail.com (S.D.)

\begin{abstract}
Biochar, prepared from organic waste materials, can improve the quality of contaminated soil areas. Biochar can be used as an economic centerpiece over other available resources and can properly utilize large amounts of waste. Soil contaminated with cadmium (Cd) is a worldwide problem that poses potential agricultural and human health hazards. Moreover, Cd toxicity causes serious problems for sustainable food production, especially in food crops like barley. High cadmium concentration in soil is phytotoxic and decreases plant growth and ultimately yields. Biochar and ascorbic acid in ameliorating Cd stress are economically compatible and consistent approaches in agriculture. The present study aimed to evaluate biochar's and foliar-applied ascorbic acid's influence on some growth and biochemical characteristics of barley (Hordeum vulgare L.) to Cd stress. The soil was supplemented with biochar $2 \% w / w$ and $20 \mathrm{mg} \mathrm{Cd} \mathrm{kg}^{-1}$. The foliar application of $30 \mathrm{mM}$ ascorbic acid was done on plants. The results revealed that $\mathrm{Cd}$ stress decreased chlorophyll a, chlorophyll $\mathrm{b}$, total chlorophyll, and carotenoids. It also increased oxidative stress indicators, i.e., APX, COD, POD, flavonoids, anthocyanin, phenolics, and electrolyte leakage, in barley with Cd-contamination. A significant enhancement in root and shoot length, gas exchange attributes, and chlorophyll contents validated the effectiveness of Bio + Asa treatments over all other treatments under Cd contamination. In conclusion, the sole applications of biochar and Asa in Cd contamination are also effective, but Bio + Asa is a better amendment for Cd stress alleviation in barley plants.
\end{abstract}

Keywords: biochar; physiological attributes; growth attributes; antioxidants; barley; ascorbic acid; cadmium-contaminated soil

\section{Introduction}

The agriculture sector faces many problems, including more food production and mitigation of environmental stress factors to secure future food demands [1]. Soil contamination by trace elements is one of the predominant abiotic stresses that decrease plant productivity. In addition, metal contamination deteriorates food quality and affects human health by entering the food chain. Soil contamination with trace elements is mainly due 
to anthropogenic activities, including overuse of fertilizers, mining, industrial wastes, and pesticides in agricultural areas. The natural contributors of trace elements to the environment are the weathering of rocks and volcanic activities [2].

Trace element toxicity in plants includes both biologically essential and non-essential elements $(\mathrm{Zn}, \mathrm{Co}, \mathrm{Cu}, \mathrm{Mn}, \mathrm{Cd}, \mathrm{Cr}$, As, and $\mathrm{Pb})$. Plant uptake all these elements only in trace amounts for normal functions, and they are called micronutrients [3-8]. Whenever any of these elements are present at elevated concentrations, it causes metal toxicity $[2,9,10]$. Soils polluted with metal elements pose severe ecological constraints, as these are not environmentally biodegradable and persistent, ultimately threatening living organisms, especially humans [2,11-15].

Plant uptake trace elements from the soil through roots and their absorbance depend upon their bioavailability in soils. Therefore, plant roots are the first organ that experiences $\mathrm{Cd}$ toxicity and enhanced oxygen radicals production and growth inhibition [16]. Cadmium is the 7th one among 20 metals causing toxicity to plants. The availability of $\mathrm{Cd}$ depends on other cation concentrations, cation exchange capacity, soil $\mathrm{pH}$, soil texture, and organic matter [17]. By reducing trace elements' bioavailability, their uptake can be reduced due to the stabilization of trace metals and organic pollutants in the soil. In recent approaches, biochar application as a soil amendment of heavy metal toxicity has proved effective and is widely accepted [18-20]. Biochar minimizes the absorption of trace elements by roots, thus lowering its toxicity and increasing soil fertility. Additionally, the addition of biochar to soil increases soil carbon sequestration and biological activities and decreases greenhouse gas emissions [2].

Alternatively, using several hormones, osmo-protectants, minerals, and vitamins would be another promising option under abiotic stresses and could protect several crops such as barley [21]. For example, ascorbic acid (Asa) is a water-soluble vitamin and is well known to scavenge oxidative stress efficiently, and it reduces the number of free radicals that are generated as a consequence of several abiotic stress factors [21]. The foliar-applied ascorbic acid enhances its indigenous production in plant cells, thus mitigating stressful conditions [22,23]. Ascorbic acid is helpful in the maintenance of photosynthesis, cell wall expansion, plant hormone production, regulation of antioxidant systems, ion uptake, biological yield, and harvest index [21,24,25].

Barley (Hordeum vulgare L., Gramineae) is the fourth major cereal grain among cereal crops worldwide [1,21]. However, its cultivation in Pakistan is continuously decreasing because of insufficient compost use, poor soil health, and allied abiotic stresses [26]. In 2014, Pakistan produced 67 thousand tonnes, which now in 2019 and 2020 has become 63 thousand tonnes [27]. It is consumed for humans and used as fodder for livestock and in the malting and brewing process $[21,28]$. In the current experimental study, the effect of biochar and ascorbic acid application was studied using a pot experiment on barley subjected to Cd stress. Their performance was assessed in terms of growth, photosynthetic pigments, antioxidant activities, and ion accumulation. It was hypothesized that plants with ascorbic acid and biochar might perform better than untreated barley plants under $\mathrm{Cd}$ stress. In the current study, barley was selected as an essential nutritional crop, as it is economically important and among the most widely consumed plants.

\section{Materials and Methods}

\subsection{Seed Sterilization}

Seeds of barley (Hordeum vulgare L. Genotype B-14011) were obtained from Ayub Agriculture Research Institute, Faisalabad, Pakistan. All seeds were disinfected using $95 \%$ ethanol for $1 \mathrm{~min}$; then, a $70 \%$ sodium hypochlorite solution $(\mathrm{NaOHCl})$ for $10 \mathrm{~min}$. The seeds were washed with distilled water six times.

\subsection{Experimental Design}

In 2020, a pot experiment was performed in the greenhouse of the Old Botanical Garden, University of Agriculture Faisalabad, Faisalabad, Pakistan. The treatments con- 
sisted of (a) control, (b) biochar, (c) biochar + ascorbic acid = Bio + Asa, (d) ascorbic acid spray = Asa, arranged into two groups: (Cd-contaminated and non-contaminated) and 3 replications in a completely randomized design (CRD).

\subsection{Seeds Sowing and Pot Preparation}

Barley seeds were sown in plastic pots filled with $5 \mathrm{~kg}$ of soil. The sowing season was January 2020. The seedlings were irrigated thrice a week until the termination of the experiment. Each $5 \mathrm{~kg}$ plastic pot was provided the desired dose of biochar (non-biochar and $2 \% w / w$ of pot soil). The biochar was prepared from pyrolysis of air-dried vegetable waste and then was powdered and sieved through a $2 \mathrm{~mm}$ sieve.

\subsection{Cadmium (Cd) Contamination}

$\mathrm{Cd}$ treatment was prepared by spraying the reagent into the soil. Cadmium nitrate $\left(\mathrm{Cd}\left(\mathrm{NO}_{3}\right)_{2} \cdot 4 \mathrm{H}_{2} \mathrm{O}\right)$ was mixed to attain the homogenized concentration of $20 \mathrm{mg} \mathrm{Cd} \mathrm{kg}^{-1}$ of dry soil, keeping in mind the threshold limit in the plant $(0.2-1.5 \mathrm{ppm})$ and soil (3-6 mg kg-1 soil) suggested by the Commission Regulation (EU) [29], the Indian standard [30], and the WHO/FAO [31].

\subsection{Ascorbic Acid (Asa)}

The solution of Asa was prepared with a $30 \mathrm{mM}$ strength containing $0.1 \%$ of Tween 20 (Polysorbate 20) as a surfactant. Controlled barley plants were only sprayed with distilled water. The ascorbic acid foliar application was provided four weeks after sowing. The plants were harvested after 45 days of sowing. The concentrations of Asa, $\mathrm{Cd}$, and biochar in the present study were considered from the literature.

\subsection{Growth Attributes}

The lengths of soot and roots were determined using a measuring tape. Immediately after harvesting, the fresh weight was estimated by using a digital weighing balance. The samples were preserved at $-30^{\circ} \mathrm{C}$ for a more fresh analysis. Sample plants from individual treatments were oven-dehydrated at $65^{\circ} \mathrm{C}$ for 3 days.

\subsection{Measurement of Chlorophyll Contents and Gas Exchange Characteristics}

Gaseous exchange parameters: the transpiration rate, the stomatal conductance, and the photosynthetic rate were measured on leaves of three plants. Each replicate used the infrared gas analyzer (Cl-340 Handheld Photosynthesis System, Washington, DC, USA). All these measurements were recorded between 11 a.m. and 2 p.m. with a photosynthetic photon flux density (PPFD) not lower than $1800 \mu \mathrm{mol} \mathrm{m} \mathrm{m}^{-2} \mathrm{~s}^{-1}$. The total chlorophyll was estimated following the Lichtenthaler and Wellburn [27] method. In addition, chlorophyll a, chlorophyll b, and carotenoid contents were measured as stated by the standard Arnon [28] protocol. For this, fresh leaves $(0.1 \mathrm{~g})$ were homogenized in $8 \mathrm{~mL}$ of acetone $(95 \%)$ at $4{ }^{\circ} \mathrm{C}$ for 1 day in the dark. The optical density was recorded at 646,663 , and $450 \mathrm{~nm}$ by a spectrophotometer (UV-2550; Shimadzu, Kyoto, Japan).

\subsection{Electrolyte Leakage}

Plant electrolyte leakage (EL) was estimated by incubating leaves at $23{ }^{\circ} \mathrm{C}$ in distilled water for $24 \mathrm{~h}$ in the dark. Next, the samples were vortexed, and initial electrical conductivity was recorded by using a conductivity meter. Then, at $60^{\circ} \mathrm{C}$, samples were autoclaved for $15 \mathrm{~min}$. Then final conductivity of samples was measured after cooling at room temperature. The following equation was used to calculate the electrolyte leakage [32]:

$$
\text { Electrolyte leakage }(E L \%)=\left(\frac{\text { Initial Electrical Conductivity }}{\text { Final Electrical Conductivity }}\right) \times 100
$$




\subsection{Oxidative Stress Indicators}

Malondialdehyde (MDA) contents were estimated by grinding $0.1 \mathrm{~g}$ fresh samples at $4{ }^{\circ} \mathrm{C}$ in a $50 \mathrm{mM}$ concentration of $25 \mathrm{~mL}$ phosphate buffer with $7.8 \mathrm{pH}$ and $1 \%$ concentrated polyethene pyrrole solution. The homogenous reaction mixture was then centrifuged at $10,000 \times \mathrm{g}$ for $15 \mathrm{~min}$ at $4{ }^{\circ} \mathrm{C}$. After this, the solution was heated at $100{ }^{\circ} \mathrm{C}$ for $20 \mathrm{~min}$ and immediately cooled in ice-cold water. The color intensity was recorded at 450, 532, and $600 \mathrm{~nm}$ wavelengths. Lipid peroxidation was indicated as $1 \mathrm{~mol} \mathrm{~g}^{-1}$ following the protocol provided by Heath and Packer [33].

$$
\operatorname{MDA}\left(\mu \mathrm{mol} \mathrm{g}^{-1}\right)=6.45(\mathrm{~A} 532-\mathrm{A} 600)-(0.56 \times \mathrm{A} 450)
$$

The determination of $\mathrm{H}_{2} \mathrm{O}_{2}$ levels of barley plant samples was done by homogenously mixing $3 \mathrm{~mL}$ of leaf extract, $1 \mathrm{~mL}$ of $0.1 \%$ titanium sulfate, and $20 \% \mathrm{H}_{2} \mathrm{SO}_{4} v / v$. The solution was centrifuged at $6000 \times g$ for about $15 \mathrm{~min}$. The colour absorbance was recorded at $410 \mathrm{~nm}$ by using a spectrophotometer. $\mathrm{H}_{2} \mathrm{O}_{2}$ contents were measured by a $0.28 \mathrm{mmol}^{-1} \mathrm{~cm}^{-1}$ extinction coefficient, followed by Jana and Choudhuri [34].

\subsection{Determination of Antioxidant Enzymatic Activities}

Peroxidase (POD) enzyme activity in the leaves was found as reported by the Sakharov and Ardila [32] method by using a guaiacol catalyst. Three $\mathrm{mL}$ of the reaction mixture was prepared with $0.05 \mathrm{~mL}$ of enzyme concentrate, $2.75 \mathrm{~mL}$ of phosphate buffer with a $50 \mathrm{mM}$ strength and $7.0 \mathrm{pH}, 0.1 \mathrm{~mL}$ of $1 \% \mathrm{H}_{2} \mathrm{O}_{2}$, and $0.1 \mathrm{~mL}$ of $4 \%$ guaiacol solution. Absorbance was noted at a $470 \mathrm{~nm}$ wavelength. The unit enzyme activity was accounted for as the contents of peroxidase enzyme present.

Catalase (CAT) concentration in cells was assayed by following the Aebi [33] method. For this, $3.0 \mathrm{~mL}$ of a reaction mixture comprised $100 \mathrm{~L}$ of enzyme extract, $100 \mathrm{~L}$ of $300 \mathrm{mM}$ concentrated $\mathrm{H}_{2} \mathrm{O}_{2}, 2.8 \mathrm{~mL}$ of $50 \mathrm{mM}$ phosphate buffer, along with $2 \mathrm{mM}$ of ETDA with a $\mathrm{pH}=7.0$. The activity of the CAT enzyme was measured at 240 by a decline in absorbance as by $\mathrm{H}_{2} \mathrm{O}_{2}$ loss. Finally, the superoxide dismutase (SOD) activity was estimated by following the Beauchamp and Fridovich method [35].

\subsection{Estimation of Proline, Sugars, and Non-Enzymatic Antioxidants}

To estimate proline and soluble sugars and several non-enzymatic antioxidants, ethanol extracts of leaf samples were prepared using $50 \mathrm{mg}$ of dried leaf material and were homogenized in $10 \mathrm{~mL}$ of $80 \%$ ethanol. Then, this solution was filtered, followed by re-extraction in ethanol. The $20 \mathrm{~mL}$ of the final volume was maintained by mixing both sample extracts, and this mixture was used to determine contents like total soluble proteins [36], anthocyanin [37], phenolics [38], flavonoids [39], total sugars [40], and ascorbic acid [41] contents.

For the estimation of proline, $0.1 \mathrm{~g}$ of fresh leaves were extracted in a $5 \mathrm{~mL}$ sulfosalicylic acid $(3 \%)$ and then centrifuged $($ at $10,000 \times g)$ for $15 \mathrm{~min}$. After this, a $1 \mathrm{~mL}$ aliquot was taken in a test tube containing $1 \mathrm{~mL}$ of glacial acetic acid and $1 \mathrm{~mL}$ of acidic ninhydrin mixture. It was then boiled for $10 \mathrm{~min}$ at $100{ }^{\circ} \mathrm{C}$ and immediately cooled down in an ice bath and then vortexed for $20 \mathrm{~s}$ and cooled down at room temperature. Absorbance at a $520 \mathrm{~nm}$ wavelength was recorded using a spectrophotometer [42].

\subsection{Analysis of Cadmium Contents}

The leaf samples were immersed in $\mathrm{HNO}_{3}-\mathrm{HClO}_{4}(3: 1, v / v)$ overnight [43]. Then, $5.0 \mathrm{~mL}$ of $\mathrm{HNO}_{3}$ and digesting samples on the hot plate were added until a clear solution was obtained. Cd contents were evaluated using an atomic absorption spectrophotometer. $\mathrm{Cd}$ concentration measurements were estimated from the working curve after calibrating the instrument with the standards of known concentrations [44]. 


\subsection{Statistical Analysis}

A two-way analysis of variance (ANOVA) was carried out for data evaluation, and the difference in treatments was determined. A mean comparison test between treatments was made using the least significant difference test $(p<0.05)$ [45]. Logarithmic transformations for data normalization were performed where necessary before analysis. To compute associations among various analyzed variables, we implemented Pearson's correlation analysis. The graphical demonstration of data was carried out by Origin 2021 [46].

\section{Results}

\subsection{Root and Shoot Length}

The effect of applied treatments was significant on root and shoot length. The results showed that Bio + Asa were significantly different from control-treated plants for improving the root length in Cd-contaminated and non-contaminated soils. In Cd-contaminated soils, biochar and Asa were statistically alike with Bio + Asa for root length. However, Bio + Asa were significantly better over biochar and Asa under non-contamination for root length (Figure 1A). For shoot length, no significant change was noted between Bio + Asa and biochar under $\mathrm{Cd}$ contamination. However, Bio + Asa and biochar significantly improved shoot length over Asa and the control under Cd contamination. Bio + Asa differed significantly for an increase in shoot length in non-contaminated soils. Application of biochar and Asa remained non-significant with one another but differed significantly over the control for an increase in shoot length under non-contaminated conditions (Figure 1B).
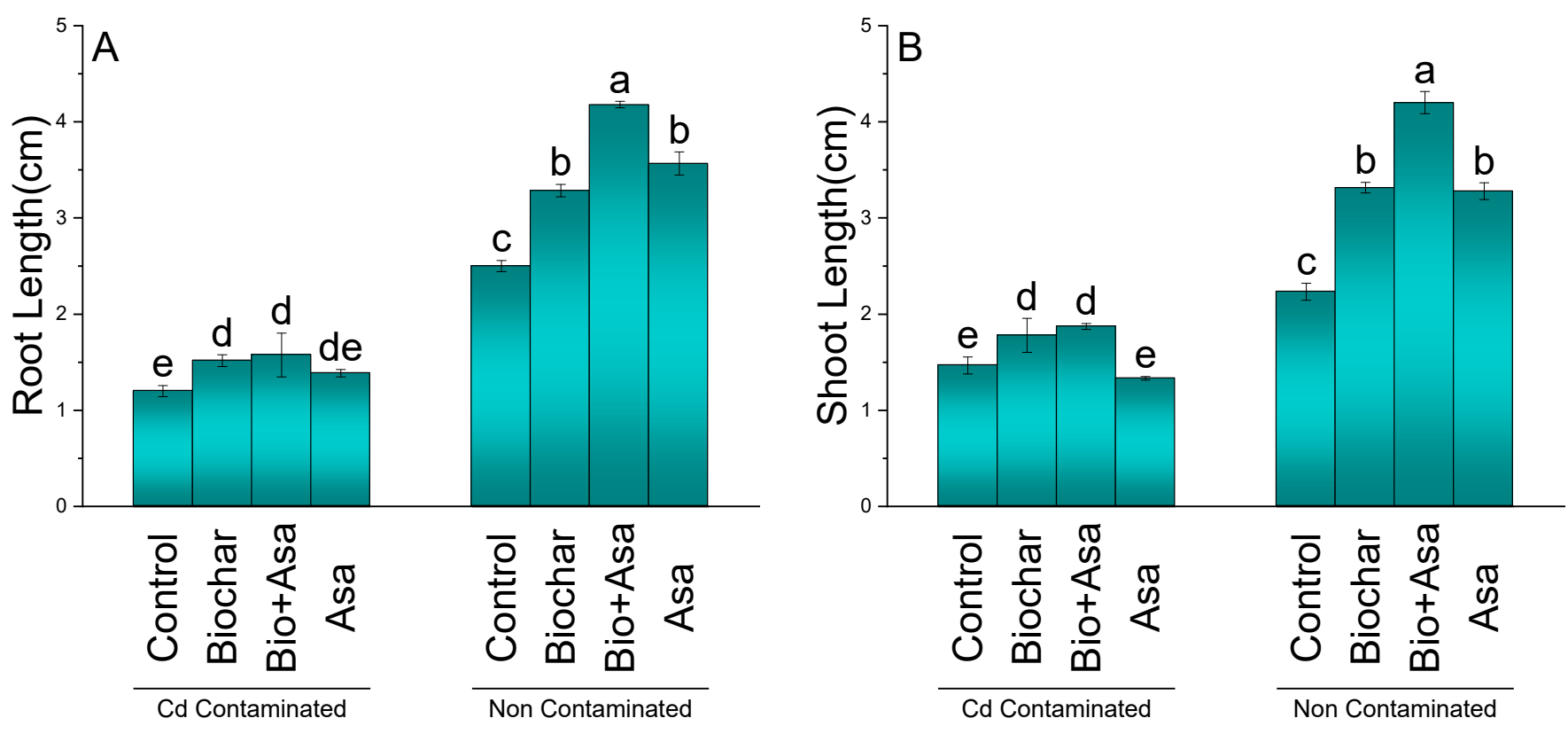

Figure 1. Impact of various treatments on root (A) and shoot (B) length of barley plants under Cd-contaminated and non-contaminated soils after 35 days of growth in pots. All values are means of 3 replicates \pm SD. Different letters on bars are significantly different at $p<0.05$ according to LSD test. Bio + Asa: biochar + ascorbic acid, Asa: ascorbic acid.

\subsection{Chlorophyll Contents}

Application of treatments significantly affects the chlorophyll $a, b$, and total chlorophyll contents under Cd-contaminated and non-contaminated soils. Chlorophyll a was significantly decreased in $\mathrm{Cd}$ contamination over non-Cd contamination without amendments. A significant increase in chlorophyll a was observed where Bio + Asa was applied compared to the control under Cd-contaminated soil. Biochar also differed significantly for improvement in chlorophyll a over Asa and the control in Cd-contaminated soil. No significant change was noticed among biochar and Bio + Asa for chlorophyll a under 
non-Cd-contaminated soils. However, biochar, Bio + Asa, and Asa significantly enhanced chlorophyll a in non-Cd-contaminated soils (Figure 2A).
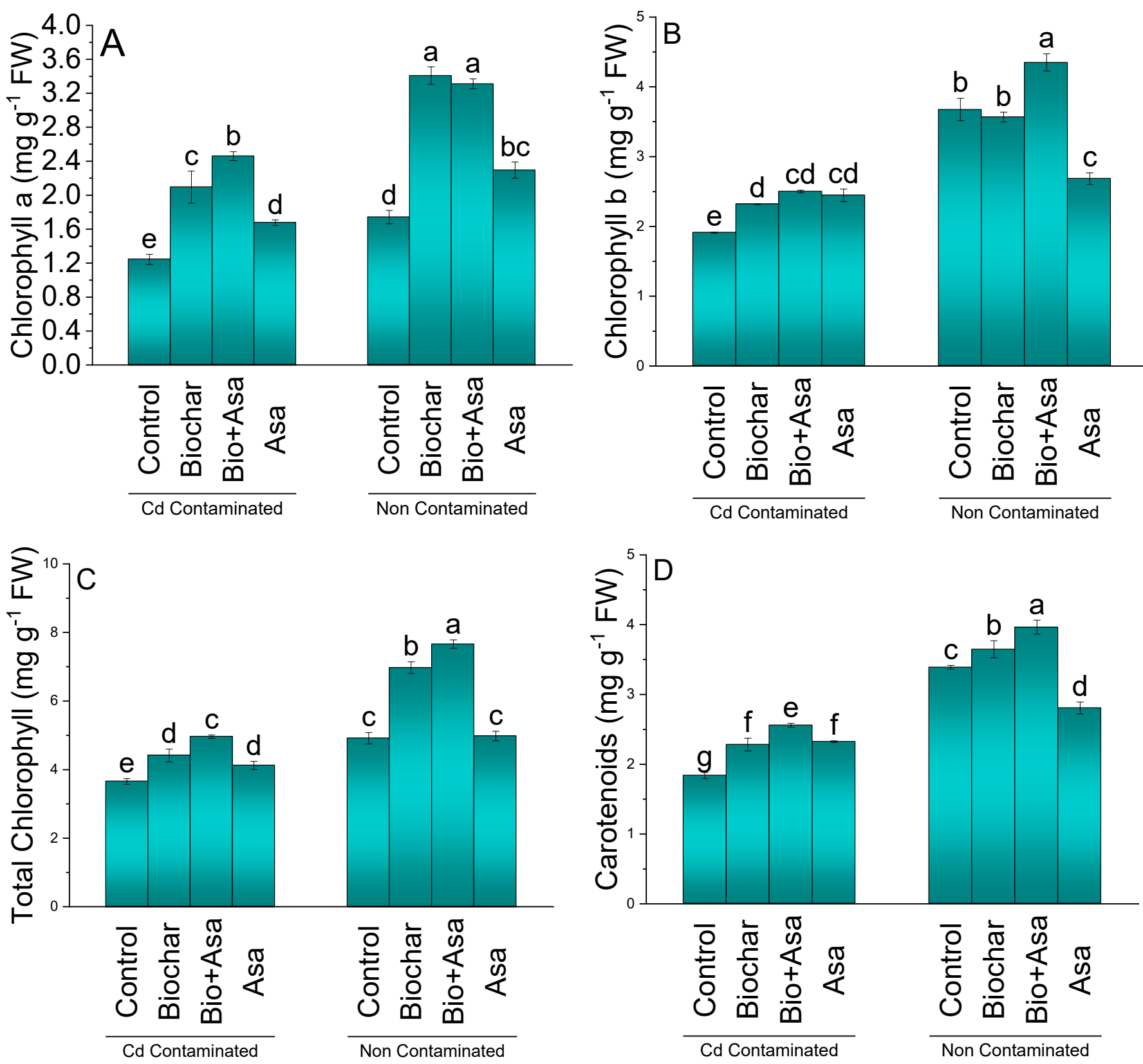

Figure 2. Effect of various treatments on chlorophyll a (A), chlorophyll b (B), total chlorophyll (C), and carotenoids (D) of barley plants under $\mathrm{Cd}$-contaminated and non-contaminated soils after 35 days of growth in pots. All values are means of 3 replicates \pm SD. Different letters on bars are significantly different at $p<0.05$ according to LSD test. Bio + Asa: biochar + ascorbic acid, Asa: ascorbic acid.

For chlorophyll b, Bio + Asa, Asa, and biochar remained significantly different from the control under Cd-contaminated soils. Application of Bio + Asa significantly increased chlorophyll $\mathrm{b}$ among all the treatments in non-Cd-contaminated soils. However, Asa caused a significant decrease in chlorophyll $b$ over biochar and the control in non-Cdcontaminated soils. Biochar was statistically alike with the control for chlorophyll $b$ in non-Cd-contaminated soil (Figure 2B).

The Bio + Asa treatment was significantly best for improvement in total chlorophyll compared to control plants in Cd-contaminated soil. Sole application of biochar and Asa also remained significantly better for enhancing the total chlorophyll over the control under 
Cd contamination. However, the biochar application was significantly better than Asa for enhancement in total chlorophyll in Cd contamination. In non-Cd-contaminated soil, Bio + Asa was significantly best for total chlorophyll over all the treatments. Biochar also differed significantly over the control and Asa for enhancement in total chlorophyll in non-Cd-contaminated soil. However, no significant change was observed between Asa and the control for total chlorophyll in non-Cd-contaminated soil (Figure 1C).

A significant increase in carotenoids validated the effectiveness of Bio + Asa overall under treatments in $\mathrm{Cd}$-contaminated and non-contaminated soils. The results also showed that the sole application of biochar also performed significantly better for enhancing carotenoids from the control under $\mathrm{Cd}$ contamination and non-contaminated conditions. Application of Asa significantly increased carotenoids in Cd-contaminated soil but caused a significant decrease in non-Cd-contaminated soil (Figure 2D).

\subsection{Gas Exchange Attributes}

The influence of treatments was significant on stomatal conductance, net photosynthesis, and the transpiration rate under non-contaminated and $\mathrm{Cd}$ contaminated conditions. No significant change among all the treatments was noted in Cd-contaminated soil for net photosynthesis. However, in non-contaminated soil, biochar and Bio + Asa remained significantly better than the control for the improvement in net photosynthesis. The Asa treatment remained non-significant for net photosynthesis over the control in non-contaminated soil (Figure 3A). In Cd-contaminated soils, all treatments were statistically alike for stomatal conductance. However, Bio + Asa and Asa significantly decreased stomatal conductance over biochar and the control, for stomatal conductance under non-Cd-contaminated soil (Figure 3B). For the transpiration rate, Bio + Asa differed significantly over the control in Cd-contaminated soil. All other treatments were statistically alike for a transpiration rate under Cd-contamination. In non-Cd-contaminated soil, Bio + Asa and biochar were significantly different over the control for the transpiration rate (Figure $3 \mathrm{C}$ ).

\section{4. $S O D, P O D$, and $A P X$}

For SOD (Figure 4A) and POD (Figure 4B), a significant decrease was noted where $\mathrm{Bio}+\mathrm{Asa}$, Asa, and biochar were applied under Cd contamination and non-contamination. $\mathrm{Bio}+$ Asa and Asa significantly reduced APX over biochar and the control under Cd contamination and non-contamination. No significant change in all the treatments was noted between biochar and the control for APX under Cd-contamination and non-contamination (Figure 4C).

\subsection{Catalase, Phenolics, Flavonoids, and Anthocyanin}

Bio + Asa significantly differed from the control in decreasing catalase (Figure 5A), phenolics (Figure 5B), flavonoids (Figure 5C), and anthocyanin (Figure 5D) in both Cdcontaminated and non-contaminated plants. In Cd-contaminated soils, biochar and Asa differed significantly for catalase, phenolics, flavonoids, and anthocyanin. However, biochar and Asa were significantly better over control for phenolics, flavonoids, and anthocyanin under non-Cd-contaminated soil. For catalase, biochar remained non-significant over the control under non-Cd contamination.

\subsection{Ascorbic Acid, $\mathrm{MDA}, \mathrm{H}_{2} \mathrm{O}_{2}$, and Electrolyte Leakage}

Treatments significantly affect ascorbic acid, MDA, $\mathrm{H}_{2} \mathrm{O}_{2}$ and electrolyte leakage under Cd-contaminated and non-Cd-contaminated soil. Bio + Asa, biochar, and Asa significantly decreased ascorbic acid in Cd-contaminated conditions. In non-Cd contamination, $\mathrm{Bio}+$ Asa and Asa differed significantly, but biochar remained non-significant over the control for ascorbic acid. In MDA (Figure 6A) and $\mathrm{H}_{2} \mathrm{O}_{2}$ (Figure 6B), Bio + Asa, biochar, and Asa caused a significant decline compared to the control under $\mathrm{Cd}$-contamination and non-Cd contamination. For electrolyte leakage (Figure 6C), biochar and Bio + Asa caused a significant decline, but Asa was non-significant over the control in the Cd-contamination 
condition. In non-Cd contamination, biochar, Asa, and Bio + Asa significantly decreased electrolyte leakage from the control.

察

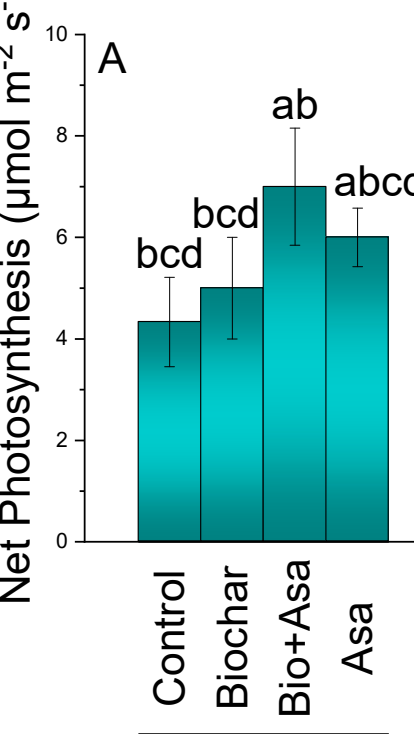

Cd Contaminated

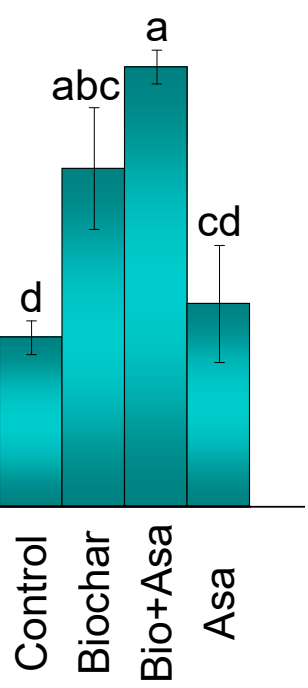

Non Contaminated
Tis

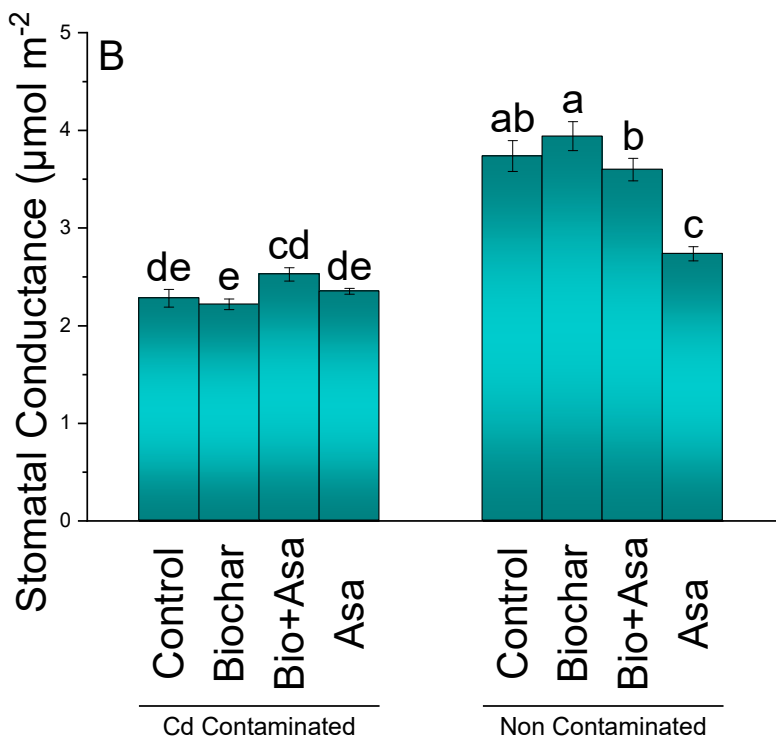

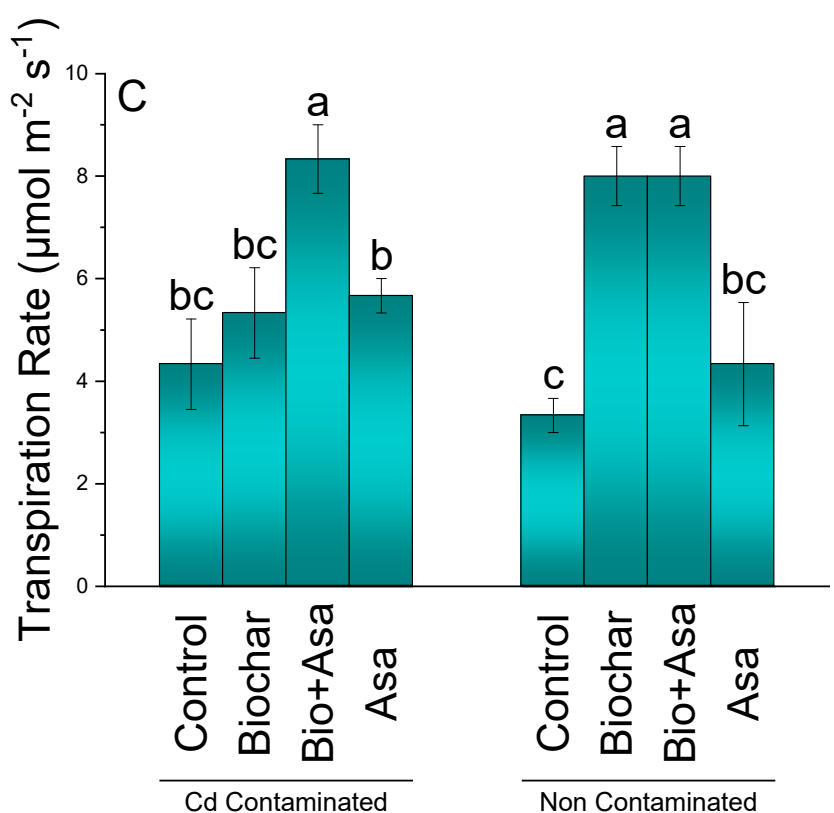

Figure 3. Effect of various treatments on net photosynthesis (A), stomatal conductance (B) and the transpiration rate (C) of barley plants under $\mathrm{Cd}$-contaminated and non-contaminated soils after 35 days of growth in pots. All values are means of 3 replicates \pm SD. Different letters on bars are significantly different at $p<0.05$ according to LSD test. Bio + Asa: biochar + ascorbic acid, Asa: ascorbic acid. 


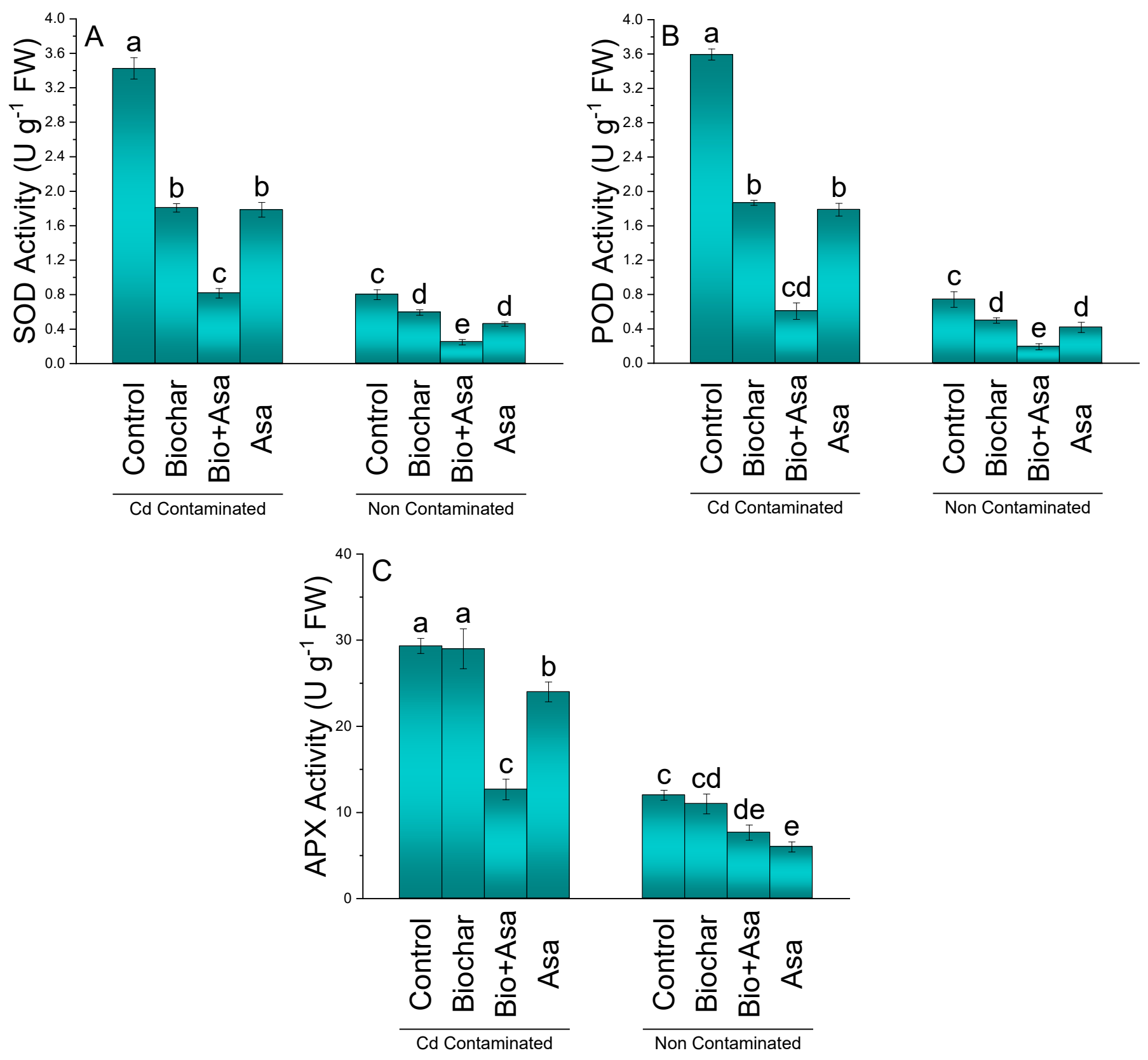

Figure 4. Effect of various treatments on SOD (A), POD (B), and APX (C) of barley plants under Cd-contaminated and non-contaminated soils after 35 days of growth in pots. All values are means of 3 replicates $\pm S D$. Different letters on bars are significantly different at $p<0.05$ according to LSD test. Bio + Asa: biochar + ascorbic acid, Asa: ascorbic acid. 

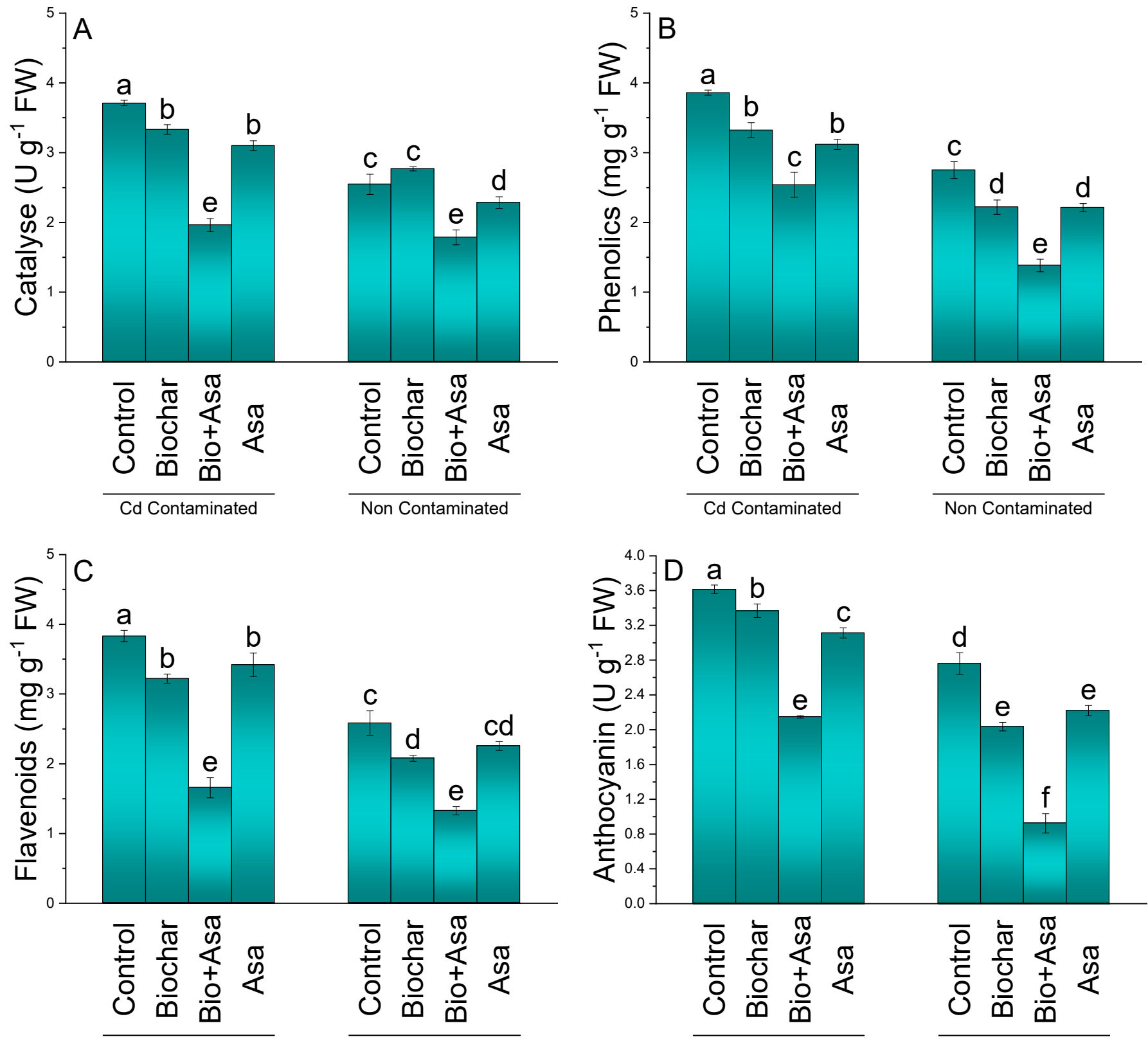

Cd Contaminated
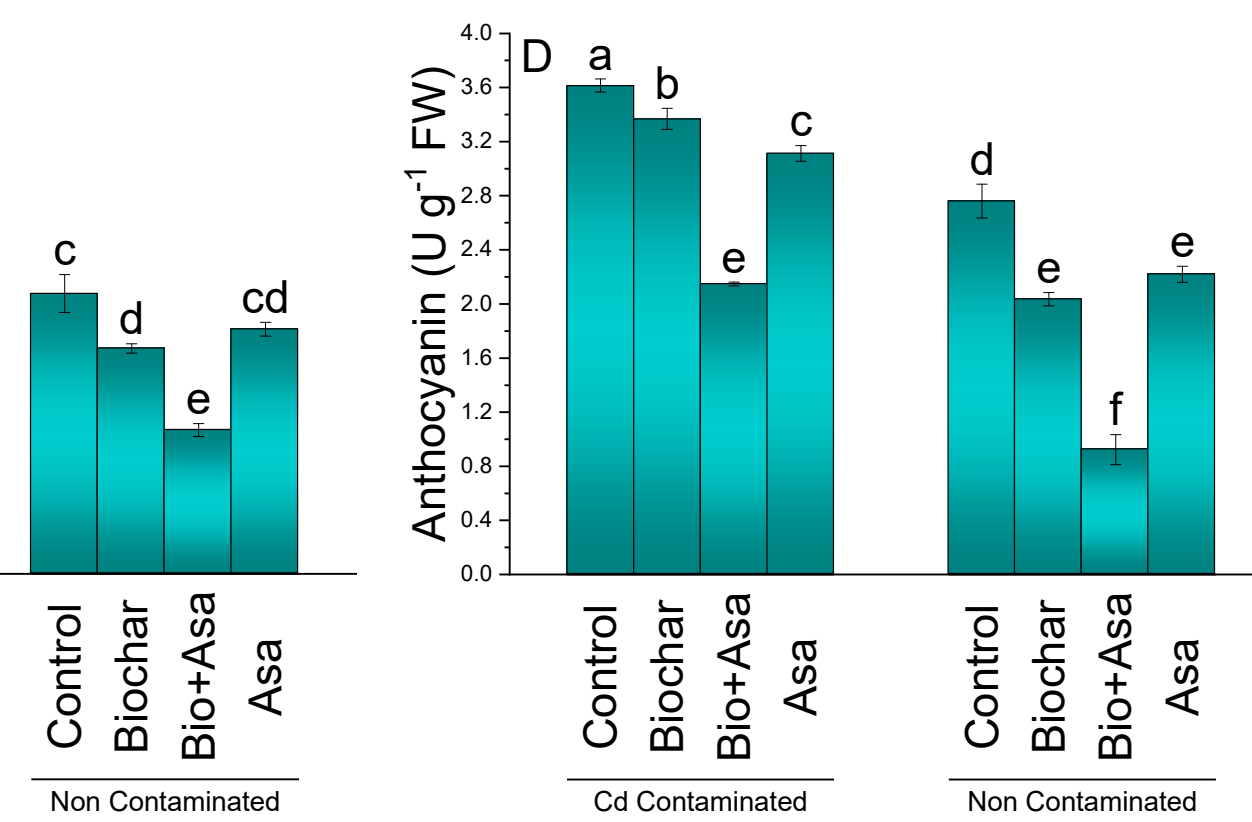

Figure 5. Effect of various treatments on catalase (A), phenolics (B), flavonoids (C), and anthocyanin (D) of barley plants under Cd-contaminated and non-contaminated soils after 35 days of growth in pots. All values are means of 3 replicates \pm SD. Different letters on bars are significantly different at $p<0.05$ according to LSD test. Bio + Asa: biochar + ascorbic acid, Asa: ascorbic acid. 

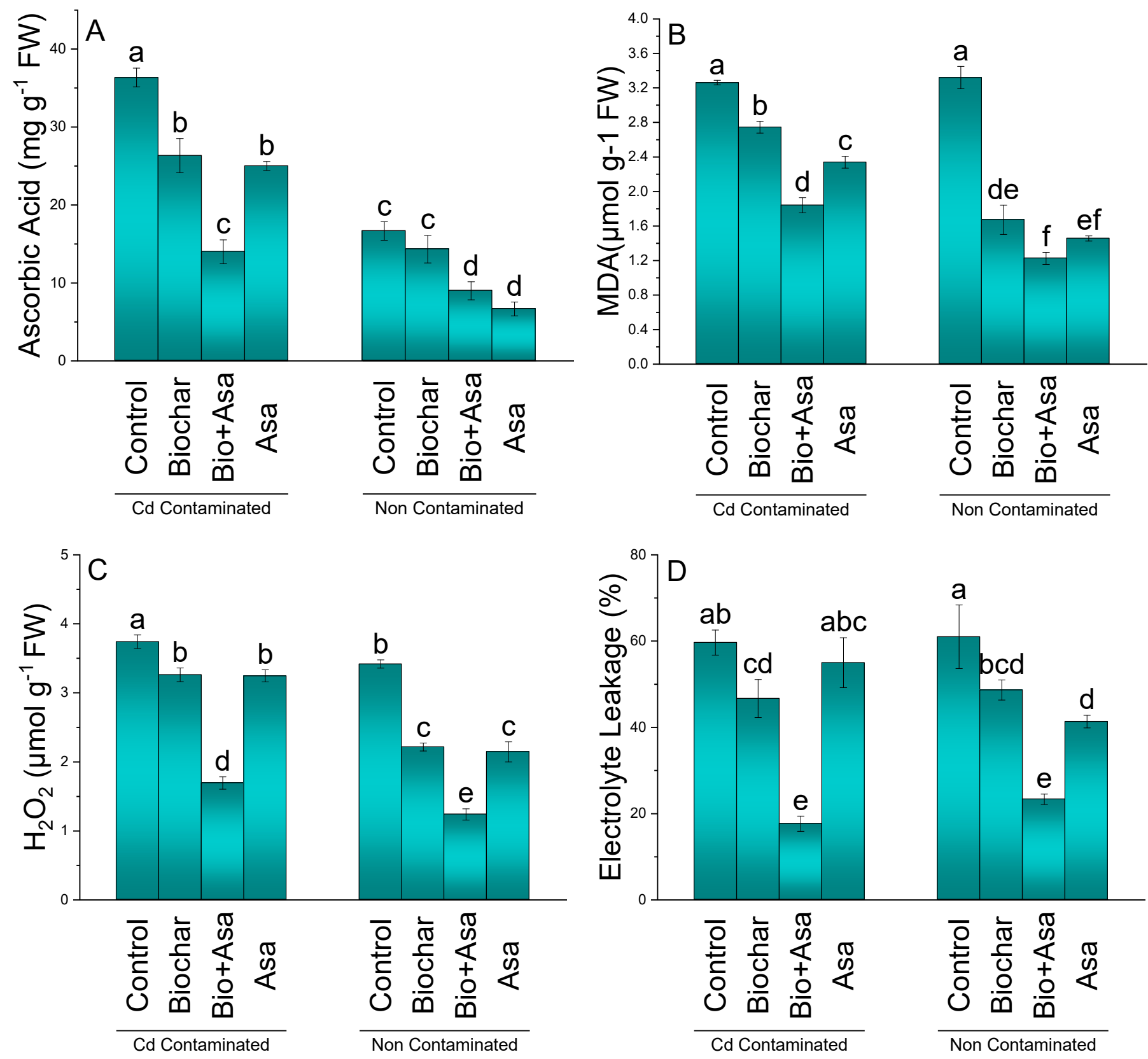

Figure 6. Effect of various treatments on ascorbic acid (A), $\mathrm{MDA}(\mathbf{B}), \mathrm{H}_{2} \mathrm{O}_{2},(\mathbf{C})$ and electrolyte leakage (D) of barley plants under Cd-contaminated and non-contaminated soils after 35 days of growth in pots. All values are means of 3 replicates \pm SD. Different letters on bars are significantly different at $p<0.05$ according to LSD test. Bio + Asa: biochar + ascorbic acid, Asa: ascorbic acid.

\subsection{Proline, Total Soluble Proteins, Root Cd Concentration, and Shoot $C d$ Concentration}

The results showed that the effect of the provided treatments was significant on proline, total soluble sugar, and $\mathrm{Cd}$ concentration in roots and shoots. Bio + Asa were significantly better over biochar and Asa for decreased proline (Figure 7A) in Cd-contaminated and non-Cd-contaminated conditions. A significant increase was noted in Bio + Asa for total soluble proteins, but the no-significant change was noticed among biochar and Asa over the control under Cd contamination. Bio + Asa and Asa significantly increased soluble sugars over the control under non-Cd contamination (Figure 7B). Bio + Asa, biochar, and Asa differed significantly over the control for the decrease in the root (Figure 7C) and shoot (Figure 7D) cadmium concentration under Cd-contaminated conditions. In noncontaminated soil, biochar and Bio + Asa were significant, but Asa was non-significant over 
the control for the decrease in the $\mathrm{Cd}$ concentration of the roots. However, Asa, biochar, and Bio + Asa remained significant for the decrease in shoot Cd concentration over the control in non-Cd-contaminated soil.
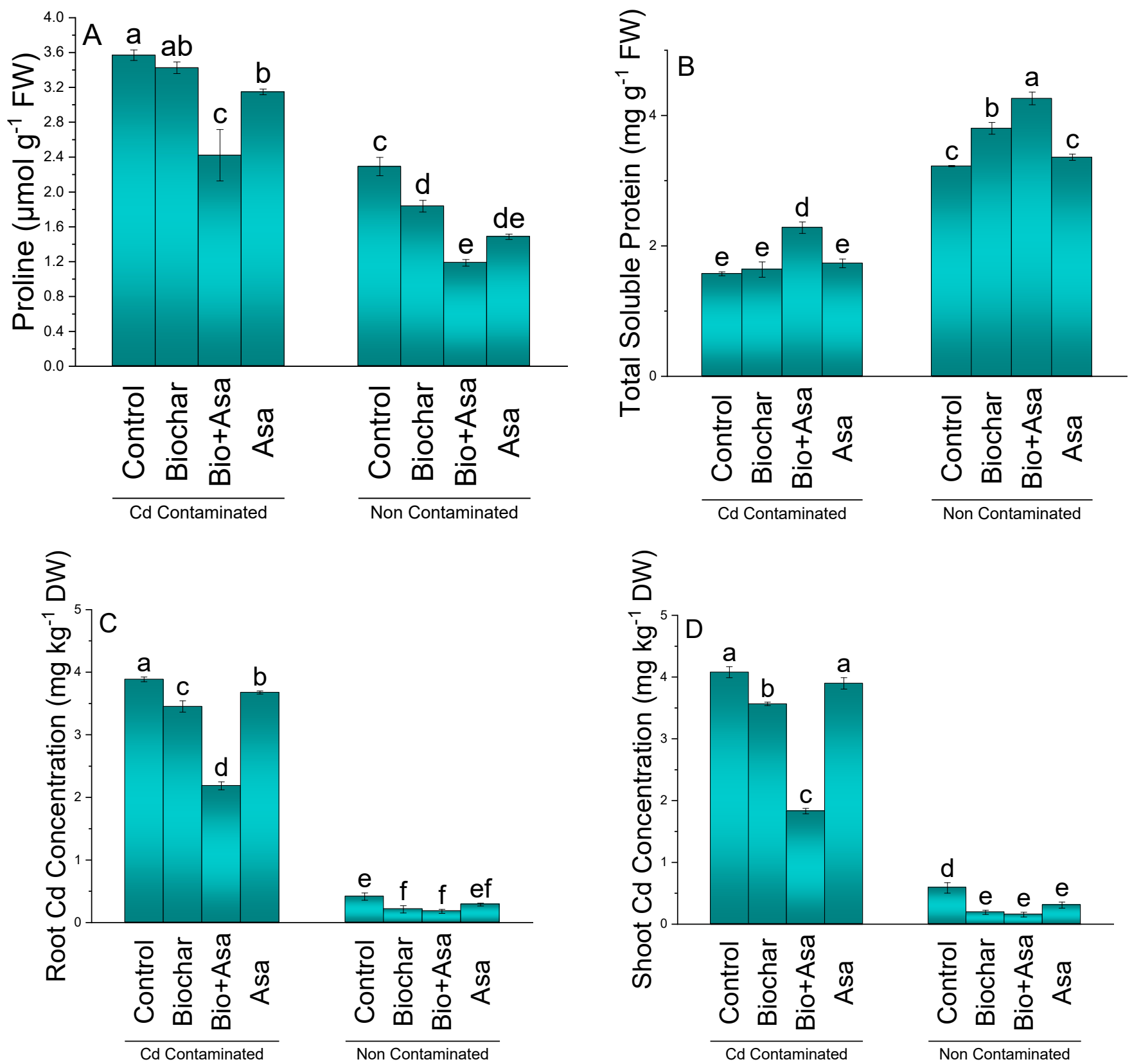

Figure 7. Effect of various treatments on proline (A), total soluble proteins (B), root Cd concentration (C), and shoot Cd concentration (D) of barley plants under Cd-contaminated and non-contaminated soils after 35 days of growth in pots. All values are means of 3 replicates \pm SD. Different letters on bars are significantly different at $p<0.05$ according to LSD test. Bio + Asa: biochar + ascorbic acid, Asa: ascorbic acid.

\subsection{Pearson Correlation}

Pearson correlation showed that shoot and root $\mathrm{Cd}$ concentration was significantly negative in correlation with shoot length, chlorophyll $a$, chlorophyll $b$, total chlorophyll contents, stomatal conductance, the transpirational rate, and total soluble sugars in Cd contamination. Attributes, i.e., SOD, POD, APX, catalyse, phenolics, flavonoids, anthocyanin, ascorbic acid, MDA, $\mathrm{H}_{2} \mathrm{O}_{2}$, electrolyte leakage, and proline, were significantly positive in correlation with shoot and root $\mathrm{Cd}$ concentration under the $\mathrm{Cd}$-contaminated condition 
(Figure 8a). In non-Cd-contaminated conditions, a parallel trend was observed. High $\mathrm{Cd}$ in shoots and roots enhanced the antioxidants and decreased the growth attributes, chlorophyll contents, and gas exchange attributes (Figure 8b).

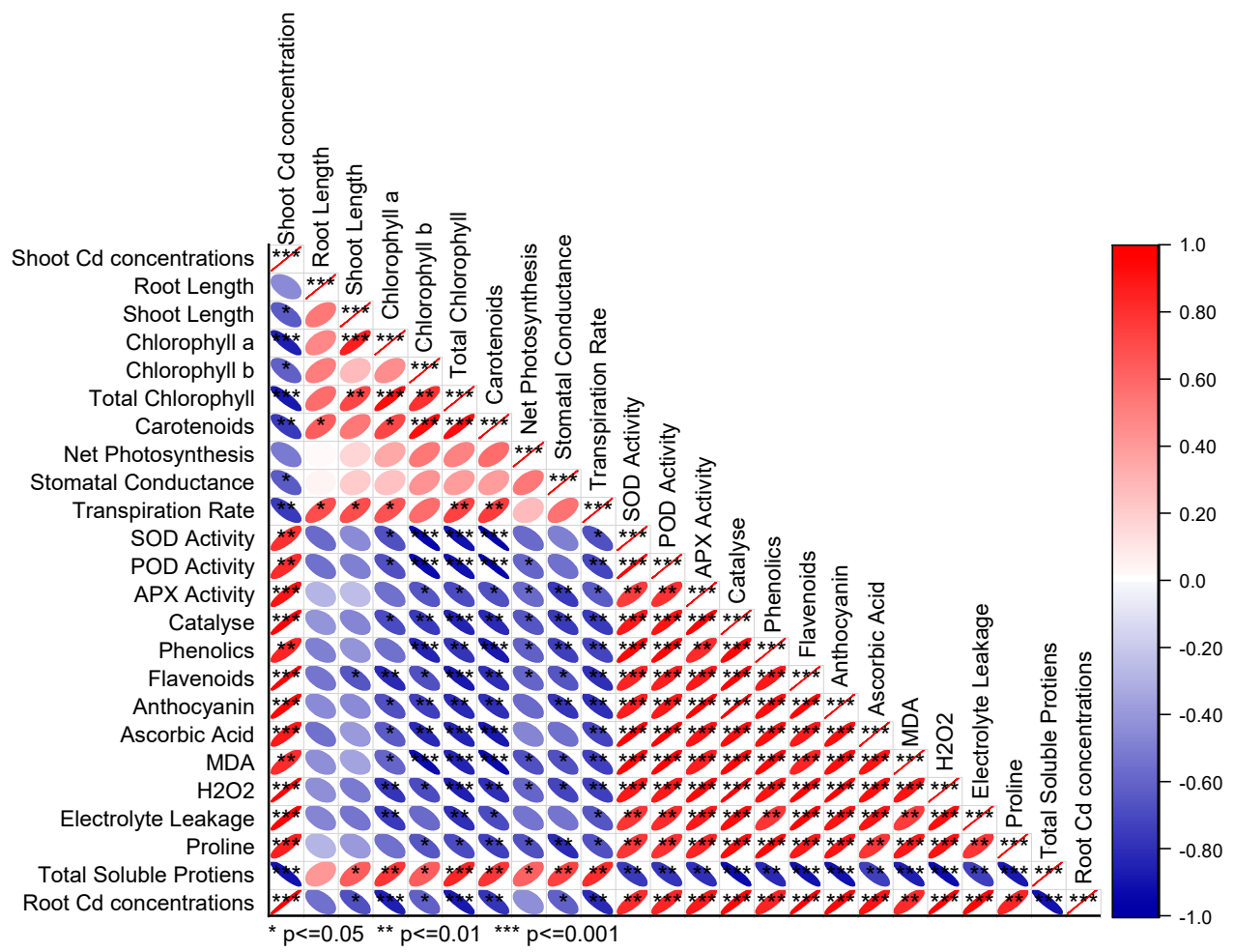

(a) Under Cd-contaminated soil

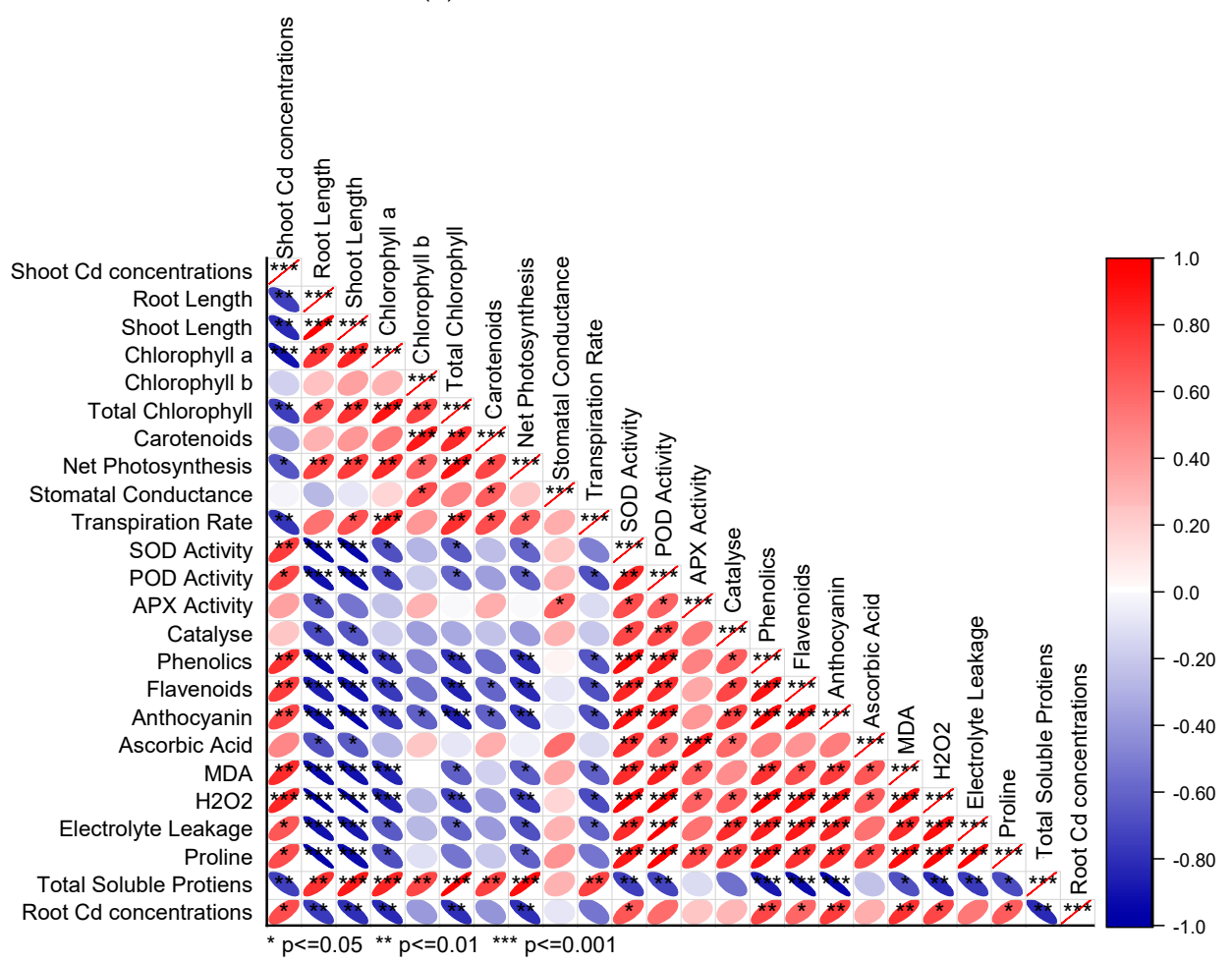

(b) Under non-Cd-contaminated soil

Figure 8. Pearson correlation of barley attributes. 


\section{Discussion}

The current study was designed to investigate the effect of biochar and ascorbic acid in Cd-contaminated soil. Barley was selected because of its major contribution to food consumption and, because of $\mathrm{Cd}$ accumulation via the food chain, it would be harmful to health. Biochar can sorb contaminants like $\mathrm{Cd}$ on its surface, thus reducing metal toxicity in plants $[47,48]$. Additionally, exogenously applied, several osmoprotectants like vitamins, minerals, and other micronutrients reduce environmental stress and improve plant vigor [21]. Therefore, in this study, the possible amendments of barley plants to $\mathrm{Cd}$ stress through foliar-sprayed ascorbic acid, biochar, and their combined application was examined by investigating its various physio-biochemical attributes. In this study, the application of treatment Bio + Asa proved effective in increasing plant length and photosynthetic pigments in cadmium stress compared to non-contaminated plants. In the literature, the increase in plant biomass, height, and photosynthetic pigment contents is linked with the antioxidant effect of ascorbic acid and biochar addition to soil [2,21].

Ascorbic acid directly reacts with several reactive oxygen species and improves plant redox status [49]. Our findings are in accordance with other ascorbic acid foliar sprays related to the plant protection mechanisms from oxidative stress, and the current study is supported by other scientific reports by Barzegar et al. [49] and Noreen et al. [21], in which foliar application with ascorbic acid spray enhanced biomass in sweet pepper [21,50].

Biochar application in Cd-polluted soils decreased $\mathrm{Cd}$ accumulation in plant tissues and grains [2]. Trace elements' removal from the rhizosphere occurs by their sorption due to the carbonaceous properties of biochar and thus decreases their availability to plants [2,51]. Similarly, Puga et al. [52] reported that the nutritional contents increased in Mucuna aterrima and Jack bean shoots with biochar application [52]. Biochar increased mineral concentrations in rice grown in paddy soil contaminated with trace elements [53]. The current experiment validates this result. An applied treatment mitigates metal stress symptoms in barley and improves plants' vigor. Their foliar application up regulates activities of non-enzymatic antioxidants like ascorbic acid under stressful conditions [21]. Kamal et al. [54] reported that ascorbic acid biosynthesis was enhanced by foliar application on cotton under heat stress [54]. Ascorbic acid is generally produced endogenously in plants during abiotic stress; however, exogenously sprayed application may further enhance its synthesis under different stress factors like soil metal contamination [55]. In the current study, a significant positive effect of Bio + Asa treatment was observed in increasing phenolic, ascorbic acid, and flavonoid concentration in barley during cadmium stress. Ascorbic acid foliar spray elevated anthocyanin contents.

Several primary and secondary metabolites, i.e., soluble sugars and proline, play an important role in cell osmotic adjustments. Proline accumulates in high concentrations during stressful conditions, which is reported in many articles [21,56-58]. Our results justify these findings. Biochar and ascorbic acid effectively increased proline and soluble sugar contents in barley in combined treatment and separate applications in Cd stress.

This is an undisputed fact that ROS are ubiquitously involved in cell signalling and that they regulate several physiological and developmental processes only in small quantities. Their concentrations become high during abiotic stress that disrupts plant metabolic activities. Antioxidants are well-known ROS scavengers [16]. In agreement with these results, enzymatic antioxidants like SOD, POD, APX activities, and catalase contents of barley plants were increased in Cd stress, and the application of Bio + Asa's combined application had significant positive effects.

Antioxidant enzymes reduce the hydrogen peroxide levels and lipid hydro peroxides, which cause membrane peroxidation, thus maintaining normal cell functions despite having high levels of ROS accumulated in root cells under Cd stress [16,59]. Our results justify these facts. In our findings, MDA levels were higher in cadmium stress, and $\mathrm{H}_{2} \mathrm{O}_{2}$ was produced in lesser amounts in ascorbic-acid-treated plants in both contaminated and non-contaminated groups. 


\section{Conclusions}

In conclusion, the application of ascorbic acid and biochar for the remediation of cadmium toxicity positively affected barley growth and physiological and yield attributes. Plant physiological parameters like shoot length and root length significantly improved with the application of Asa and biochar in mitigating Cd stress. Among all applied treatments, Bio + Asa for barley had more efficacious effects than all other treatments to ameliorate metal toxicity. Further investigation is suggested at the field level in different climatic zones to validate the current results of biochar application as an organic matter substitute with ascorbic acid for mitigation of cadmium stress in plants.

Author Contributions: Conceptualization, S.F.A.; methodology, S.F.A., N.M. and S.Y.; software, S.F.A., N.M., S.Y., S.K. and H.S.; validation, S.F.A., N.M. and S.K.; formal analysis, S.F.A., N.M., S.Y. and H.S.; investigation, S.F.A., N.M., S.Y. and S.K.; resources, E.M.E.; data curation, S.F.A., N.M., S.Y. and S.D.; writing—original draft preparation, S.F.A., N.M., S.Y., H.S., S.D., R.D. and S.K.; writing-review and editing, S.A.M.A., S.A.A., R.D. and E.M.E.; M.J.A.; supervision, E.M.E.; project administration, E.M.E.; funding acquisition, E.M.E. All authors have read and agreed to the published version of the manuscript.

Funding: The authors extend their appreciation to the Scientific Research Deanship at King Khalid University and the Ministry of Education in Saudi Arabia for funding this research work through the project number IFP-KKU-2020/3.

Institutional Review Board Statement: Not applicable.

Informed Consent Statement: Not applicable.

Data Availability Statement: Not applicable.

Conflicts of Interest: The authors declare no conflict of interest.

\section{References}

1. Hassan, A.; Amjad, S.F.; Saleem, M.H.; Yasmin, H.; Imran, M.; Riaz, M.; Ali, Q.; Joyia, F.A.; Mobeen; Ahmed, S.; et al. Foliar application of ascorbic acid enhances salinity stress tolerance in barley (Hordeum vulgare L.) through modulation of morphophysio-biochemical attributes, ions uptake, osmo-protectants and stress response genes expression. Saudi J. Biol. Sci. 2021, 28, 4276-4290. [CrossRef]

2. Rizwan, M.; Ali, S.; Qayyum, M.F.; Ibrahim, M.; Rehman, M.Z.U.; Abbas, T.; Ok, Y.S. Mechanisms of biochar-mediated alleviation of toxicity of trace elements in plants: A critical review. Environ. Sci. Pollut. Res. 2015, 23, 2230-2248. [CrossRef]

3. Ahmed, N.; Shah, A.R.; Danish, S.; Fahad, S.; Ali, M.A.; Zarei, T.; Vranová, V.; Datta, R. Immobilization of Cd in soil by biochar and new emerging chemically produced carbon. J. King Saud Univ. Sci. 2021, 33, 101472. [CrossRef]

4. Younis, U.; Qayyum, M.F.; Shah, M.H.R.; Danish, S.; Shahzad, A.N.; Malik, S.A.; Mahmood, S. Growth, survival, and heavy metal (Cd and Ni) uptake of spinach(Spinacia oleracea)and fenugreek(Trigonella corniculata)in a biochar-amended sewage-irrigated contaminated soil. J. Plant Nutr. Soil Sci. 2015, 178, 209-217. [CrossRef]

5. Awad, M.; El-Desoky, M.; Ghallab, A.; Kubes, J.; Abdel-Mawly, S.; Danish, S.; Ratnasekera, D.; Islam, M.S.; Skalicky, M.; Brestic, M.; et al. Ornamental Plant Efficiency for Heavy Metals Phytoextraction from Contaminated Soils Amended with Organic Materials. Molecules 2021, 26, 3360. [CrossRef] [PubMed]

6. Danish, S.; Zafar-ul-Hye, M.; Fahad, S.; Saud, S.; Brtnicky, M.; Hammerschmiedt, T.; Datta, R. Drought stress alleviation by ACC deaminase producing Achromobacter xylosoxidans and Enterobacter cloacae, with and without timber waste biochar in maize. Sustainability 2020, 12, 6286. [CrossRef]

7. Younis, U.; Danish, S.; Malik, S.A.; Ahmed, N.; Munir, T.M.; Rasheed, M.K. Role of cotton sticks biochar in immobilization of nickel under induced toxicity condition and growth indices of Trigonella corniculata L. Environ. Sci. Pollut. Res. 2019, 27, 1752-1761. [CrossRef] [PubMed]

8. Malik, K.; Khan, K.; Rukh, S.; Khan, A.; Akbar, S.; Billah, M.; Bashir, S.; Danish, S.; Alwahibi, M.; Elshikh, M.; et al. Immobilization of $\mathrm{Cd}, \mathrm{Pb}$ and $\mathrm{Zn}$ through Organic Amendments in Wastewater Irrigated Soils. Sustainability 2021, 13, 2392. [CrossRef]

9. Keller, C.; Rizwan, M.; Davidian, J.-C.; Pokrovsky, O.S.; Bovet, N.; Chaurand, P.; Meunier, J.-D. Effect of silicon on wheat seedlings (Triticum turgidum L.) grown in hydroponics and exposed to 0 to $30 \mu \mathrm{M} \mathrm{Cu}$. Planta 2014, 241, 847-860. [CrossRef]

10. Zaheer, I.; Ali, S.; Rizwan, M.; Farid, M.; Shakoor, M.B.; Gill, R.A.; Najeeb, U.; Iqbal, N.; Ahmad, R. Citric acid assisted phytoremediation of copper by Brassica napus L. Ecotoxicol. Environ. Saf. 2015, 120, 310-317. [CrossRef]

11. Younis, U.; Shah, M.H.R.; Danish, S.; Malik, S.A.; Ameer, A. Biochar role in improving biometric and growth attributes of $S$. oleracea and T. corniculata under cadmium stress. Int. J. Biosci. 2014, 5, 84-90. 
12. Abid, M.; Danish, S.; Zafar-ul-Hye, M.; Shaaban, M.; Iqbal, M.M.; Rehim, A.; Qayyum, M.F.; Naqqash, M.N. Biochar in-creased photosynthetic and accessory pigments in tomato (Solanum lycopersicum L.) plants by reducing cadmium con-centration under various irrigation waters. Environ. Sci. Pollut. Res. 2017, 24, 22111-22118. [CrossRef] [PubMed]

13. Zafar-Ul-Hye, M.; Shahjahan, A.; Danish, S.; Abid, M.; Qayyum, M.F. Mitigation of cadmium toxicity induced stress in wheat by ACC-deaminase containing PGPR isolated from cadmium polluted wheat rhizosphere. Pak. J. Bot. 2018, 50, $1727-1734$.

14. Zafar-Ul-Hye, M.; Naeem, M.; Danish, S.; Khan, M.J.; Fahad, S.; Datta, R.; Brtnicky, M.; Kintl, A.; Hussain, G.S.; El-Esawi, M.A. Effect of Cadmium-Tolerant Rhizobacteria on Growth Attributes and Chlorophyll Contents of Bitter Gourd under Cadmium Toxicity. Plants 2020, 9, 1386. [CrossRef]

15. Shah, A.; Bibi, F.; Hussain, I.; Yasin, N.; Akram, W.; Tahir, M.; Ali, H.; Salem, M.; Siddiqui, M.; Danish, S.; et al. Synergistic Effect of Bacillus thuringiensis IAGS 199 and Putrescine on Alleviating Cadmium-Induced Phytotoxicity in Capsicum annum. Plants 2020, 9, 1512. [CrossRef]

16. Tamás, L.; Mistrík, I.; Alemayehu, A.; Zelinová, V.; Bočová, B.; Huttová, J. Salicylic acid alleviates cadmium-induced stress responses through the inhibition of $\mathrm{Cd}$-induced auxin-mediated reactive oxygen species production in barley root tips. J. Plant Physiol. 2015, 173, 1-8. [CrossRef]

17. Mehdizadeh, L.; Farsaraei, S.; Moghaddam, M. Biochar application modified growth and physiological parameters of Ocimum ciliatum L. and reduced human risk assessment under cadmium stress. J. Hazard. Mater. 2020, 409, 124954. [CrossRef] [PubMed]

18. Zafar-ul-Hye, M.; Tahzeeb-ul-Hassan, M.; Abid, M.; Fahad, S.; Brtnicky, M.; Dokulilova, T.; Datta, R.; Danish, S. Potential role of compost mixed biochar with rhizobacteria in mitigating lead toxicity in spinach. Sci. Rep. 2020, 10, 12159. [CrossRef]

19. Zafar-Ul-Hye, M.; Tahzeeb-Ul-Hassan, M.; Wahid, A.; Danish, S.; Khan, M.J.; Fahad, S.; Brtnicky, M.; Hussain, G.S.; Battaglia, M.L.; Datta, R. Compost mixed fruits and vegetable waste biochar with ACC deaminase rhizobacteria can minimize lead stress in mint plants. Sci. Rep. 2021, 11, 6606. [CrossRef] [PubMed]

20. Danish, S.; Tahir, F.A.; Rasheed, M.K.; Ahmad, N.; Ali, M.A.; Kiran, S.; Younis, U.; Irshad, I.; Butt, B. Effect of foliar application of Fe and banana peel waste biochar on growth, chlorophyll content and accessory pigments synthesis in spinach under chromium (IV) toxicity. Open Agric. 2019, 4, 381-390. [CrossRef]

21. Noreen, S.; Sultan, M.; Akhter, M.S.; Shah, K.H.; Ummara, U.; Manzoor, H.; Ulfat, M.; Alyemeni, M.N.; Ahmad, P. Foliar fertigation of ascorbic acid and zinc improves growth, antioxidant enzyme activity and harvest index in barley (Hordeum vulgare L.) grown under salt stress. Plant Physiol. Biochem. 2020, 158, 244-254. [CrossRef]

22. Billah, M.; Rohman, M.M.; Hossain, N.; Uddin, M.S. Exogenous ascorbic acid improved tolerance in maize (Zea mays L.) by increasing antioxidant activity under salinity stress. Afr. J. Agric. Res. 2017, 12, 1437-1446. [CrossRef]

23. Agami, R.A. Applications of ascorbic acid or proline increase resistance to salt stress in barley seedlings. Biol. Plant. 2014, 58, 341-347. [CrossRef]

24. Alayafi, A.A.M. Exogenous ascorbic acid induces systemic heat stress tolerance in tomato seedlings: Transcriptional regula-tion mechanism. Environ. Sci. Pollut. Res. 2020, 27, 19186-19199. [CrossRef]

25. Wang, Y.-H.; Zhang, G.; Chen, Y.; Gao, J.; Sun, Y.-R.; Sun, M.-F.; Chen, J.-P. Exogenous application of gibberellic acid and ascorbic acid improved tolerance of okra seedlings to $\mathrm{NaCl}$ stress. Acta Physiol. Plant. 2019, 41, 1-10. [CrossRef]

26. Naheed, S.; Raza, I.; Anwar, M.Z.; Habib, N.; Zahra, N.; Siddiqui, S. Forecasting area and production of barley in Punjab, Pakistan. Pakistan J. Agric. Res. 2015, 28, 304-309.

27. Eskin, V.; Bougay, V. Pakistan Barley Production Quantity. Available online: https://knoema.com/atlas/Pakistan/topics/ Agriculture/Crops-Production-Quantity-tonnes/Barley-production (accessed on 30 July 2021).

28. Meints, B.; Hayes, P.M. Breeding naked barley for food, feed, and malt. Plant Breed. Rev. 2019, 43, $95-119$.

29. Fuster, V.; Rydén, L.E.; Cannom, D.S.; Crijns, H.J.; Curtis, A.B.; Ellenbogen, K.A.; Halperin, J.L.; Le Heuzey, J.Y.; Kay, G.N.; Lowe, J.E.; et al. Erratum: ACC/AHA/ESC 2006 guidelines for the management of patients with atrial fibrillation-executive summary. Eur. Heart J. 2007, 28, 2046. [CrossRef]

30. Awashthi, S.K. Prevention of Food Adultration; Ashoka Law House: New Delhi, India, 2000.

31. WHO/FAO. Report of the Thirty Eight Session of the Codex Committee on Food Hygiene; Joint FAO/WHO Food Standards Programme: Rome, Italy, 2007.

32. Lutts, S.; Kinet, J.M.; Bouharmont, J. NaCl-induced senescence in leaves of rice (Oryza sativa L.) cultivars differing in salinity resistance. Ann. Bot. 1996, 78, 389-398. [CrossRef]

33. Heath, R.L.; Packer, L. Photoperoxidation in isolated chloroplasts. Arch. Biochem. Biophys. 1968, 125, 189-198. [CrossRef]

34. Jana, S.; Choudhuri, M.A. Glycolate metabolism of three submersed aquatic angiosperms during ageing. Aquat. Bot. 1982, 12, 345-354. [CrossRef]

35. Beauchamp, C.; Fridovich, I. Superoxide dismutase: Improved assays and an assay applicable to acrylamide gels. Anal. Biochem. 1971, 44, 276-287. [CrossRef]

36. Bradford, M.M. A rapid and sensitive method for the quantitation of microgram quantities of protein using the principle of protein dye binding. Anal. Biochem. 1976, 72, 248-254. [CrossRef]

37. E Lewis, C.; Walker, J.R.L.; E Lancaster, J.; Sutton, K.H. Determination of anthocyanins, flavonoids and phenolic acids in potatoes. I: Coloured cultivars of Solanum tuberosum L. J. Sci. Food Agric. 1998, 77, 45-57. [CrossRef]

38. Bray, H.G.; Thorpe, W.V. Analysis of Phenolic Compounds of Interest in Metabolism. Methods Biochem. Anal. 2006, 1, 27-52. [CrossRef] 
39. Pękal, A.; Pyrzynska, K. Evaluation of Aluminium Complexation Reaction for Flavonoid Content Assay. Food Anal. Methods 2014, 7, 1776-1782. [CrossRef]

40. Dubois, M.; Gilles, K.A.; Hamilton, J.K.; Rebers, P.A.; Smith, F. Colorimetric Method for Determination of Sugars and Related Substances. Anal. Chem. 1956, 28, 350-356. [CrossRef]

41. Azuma, K.; Nakayama, M.; Koshioka, M.; Ippoushi, K.; Yamaguchi, Y.; Kohata, K.; Yamauchi, Y.; Ito, H.; Higashio, H. Phenolic Antioxidants from the Leaves of Corchorus olitorius L. J. Agric. Food Chem. 1999, 47, 3963-3966. [CrossRef]

42. Bates, L.S.; Waldren, R.P.; Teare, I.D. Rapid determination of free proline for water-stress studies. Plant Soil 1973, 39, $205-207$. [CrossRef]

43. Miller, O. Nitric-Perchloric Acid Wet Digestion In an Open Vessel. In Reference Methods for Plant Analysis; Kalra, Y., Ed.; CRC Press: Washington, DC, USA, 1998; pp. 57-62.

44. Suarez, D.L. Beryllium, Magnesium, Calcium, Strontium, and Barium. In Methods of Soil Analysis: Part 3 Chemical Methods, 5.3; Sparks, D.L., Page, A.L., Helmke, P.A., Loeppert, R.H., Soltanpour, P.N., Tabatabai, M.A., Johnston, C.T., Sumner, M.E., Eds.; John Wiley \& Sons, Ltd.: Hoboken, NJ, USA, 2018; pp. 575-601.

45. Steel, R.G.; Torrie, J.H.; Dickey, D.A. Principles and Procedures of Statistics: A Biometrical Approach, 3rd ed.; McGraw Hill Book International Co.: Singapore, 1997.

46. OriginLab Corporation. OriginPro; OriginLab: Northampton, MA, USA, 2021.

47. Younis, U.; Malik, S.A.; Rizwan, M.; Qayyum, M.F.; Ok, Y.S.; Shah, M.H.R.; Rehman, R.A.; Ahmad, N. Biochar enhances the cadmium tolerance in spinach (Spinacia oleracea) through modification of Cd uptake and physiological and biochemical attributes. Environ. Sci. Pollut. Res. 2016, 23, 21385-21394. [CrossRef]

48. Rizwan, M.; Ali, S.; Adrees, M.; Rizvi, H.; Zia-Ur-Rehman, M.; Hannan, F.; Qayyum, M.F.; Hafeez, F.; Ok, Y.S. Cadmium stress in rice: Toxic effects, tolerance mechanisms, and management: A critical review. Environ. Sci. Pollut. Res. 2016, 23, 17859-17879. [CrossRef] [PubMed]

49. Siddiqui, M.H.; Alamri, S.; Al-Khaishany, M.Y.; Khan, M.N.; Al-Amri, A.; Ali, H.M.; Alaraidh, I.A.; Alsahli, A.A. Exogenous melatonin counteracts $\mathrm{NaCl}$-induced damage by regulating the antioxidant system, proline and carbohydrates metabolism in tomato seedlings. Int. J. Mol. Sci. 2019, 20, 353. [CrossRef] [PubMed]

50. Barzegar, T.; Fateh, M.; Razavi, F. Enhancement of postharvest sensory quality and antioxidant capacity of sweet pepper fruits by foliar applying calcium lactate and ascorbic acid. Sci. Hortic. 2018, 241, 293-303. [CrossRef]

51. Zhou, F.; Wang, H.; Fang, S.; Zhang, W.; Qiu, R. Pb(II), Cr(VI) and atrazine sorption behavior on sludge-derived biochar: Role of humic acids. Environ. Sci. Pollut. Res. 2015, 22, 16031-16039. [CrossRef]

52. Puga, A.; Abreu, C.; Melo, L.; Beesley, L. Biochar application to a contaminated soil reduces the availability and plant uptake of zinc, lead and cadmium. J. Environ. Manag. 2015, 159, 86-93. [CrossRef]

53. Khan, S.; Reid, B.J.; Li, G.; Zhu, Y.-G. Application of biochar to soil reduces cancer risk via rice consumption: A case study in Miaoqian village, Longyan, China. Environ. Int. 2014, 68, 154-161. [CrossRef]

54. Kamal, M.A.; Saleem, M.F.; Shahid, M.; Awais, M.; Khan, H.Z.; Ahmed, K. Ascorbic acid triggered physiochemical transformations at different phenological stages of heat-stressed Bt cotton. J. Agron. Crop Sci. 2017, 203, 323-331. [CrossRef]

55. Naz, H.; Akram, N.A.; Ashraf, M. Impact of ascorbic acid on growth and some physiological attributes of cucumber (Cu-cumis sativus) plants under water-deficit conditions. Pak. J. Bot. 2016, 48, 877-883.

56. Bose, J.; Rodrigo-Moreno, A.; Shabala, S. ROS homeostasis in halophytes in the context of salinity stress tolerance. J. Exp. Bot. 2013, 65, 1241-1257. [CrossRef]

57. Noreen, S.; Faiz, S.; Akhter, M.S.; Shah, K.H. Influence of Foliar Application of Osmoprotectants to Ameliorate Salt Stress in Sunflower (Helianthus annuus L.). Sarhad J. Agric. 2019, 35, 1316-1325. [CrossRef]

58. Noreen, S.; Shaheen, A.; Shah, K.H.; Ammara, U. Effects of Aerial Application of Salicylic Acid on Growth, Pigment Concentration, Ions Uptake and Mitigation of Salinity Stress in Two Varieties of Wheat (Triticum aestivum L.). Pak. J. Life Soc. Sci. 2019, 17, 78-85.

59. Zelinová, V.; Mistrík, I.; Pavlovkin, J.; Tamás, L. Glutathione peroxidase expression and activity in barley root tip after short-term treatment with cadmium, hydrogen peroxide and t-butyl hydroperoxide. Protoplasma 2013, 250, 1057-1065. [CrossRef] 